\title{
Diuretic and Salidiuretics Activity of an Aqueous Extract of Leafy Branches of Mimosa invisa Mart. ex. Colla (Fabaceae) in Rats
}

\author{
Irie Bi Jean Séverin', Abo Kouakou Jean Claude², Kahou Bi Gohi Parfait ${ }^{3}$ \\ 1, 2, 3 Laboratory of Animal Physiology and Pharmacology, UFR Biosciences, Felix Houphouet Boigny University, Cocody \\ 22 BP 582 Abidjan 22
}

\begin{abstract}
In this study, the aqueous extract of Mimosa invisa (Miv), at doses ranging from 5 to $20 \mathrm{mg} / \mathrm{kg} \mathrm{b.w.,} \mathrm{causes} \mathrm{a} \mathrm{dose-}$ dependent and significant increase $(p<0.001)$ of the volume of urinary excretion measured during 24 hours and at dose of $20 \mathrm{mg} / \mathrm{kg}$ $b . w$, a significant decrease $(p<0.01)$ of time of the first micturition (TFM) in rats treated. These effects of Miv suggest that this extract is a diuretic. In addition, Miv significantly increases urinary excretion of $\mathrm{Na}^{+}, \mathrm{K}^{+}$and $\mathrm{Cl}^{-}(\mathrm{p}<0.01)$. However, the urinary ratio $\mathrm{Na}^{+} / \mathrm{K}^{+}$ does not vary significantly in the presence of Miv, which is in favor of a more pronounced action of this extract on the renal tubules. In addition, the effects of Miv on diuresis and the TFM are similar to those of hydrochlorothiazide, furosemide and spirolactone at doses of $20 \mathrm{mg} / \mathrm{kg} \mathrm{b.w}$. The salidiuretic effects of Miv are also similar to those of hydrochlorothiazide and furosemide, but differs from that of the spirolactone which to him decreases $(p<0,05)$ the urinary excretion of $K$. In addition, unlike Miv, spironolactone has an increase $(\mathrm{p}<0.01)$ of the urinary ratio $\mathrm{Na}^{+} / \mathrm{K}^{+}$. This study shows that the extract of Mimosa invisa is a diuretic whose effects are similar to those of furosemide and hydrochlorothiazide. These diuretic properties of Miv justify the use of Mimosa invisa (Fabaceae) in traditional medicine to treat arterial hypertension.
\end{abstract}

Keywords: Mimosa invisa, diuretic and salidiuretic, furosemide, hydrochlorothiazide, spirolactone.

\section{Introduction}

Africa has a large variety of medicinal plants (Dibong et al., 2011) that treat various diseases. This is the case of Mimosa invisa Mart ex. Colla (Fabaceae), a plant used in traditional medicine in Africa in the treatment of arterial hypertension, diabetes and other diseases (Mansroi, 2011; Harjanti, 2009). Mimosa invisa is a shrubby plant, prostrate or ascending to trend lianescente, reaching 1-2 m (Garcia, 1982). It is native to South America, and has long been considered invasive (Larrue, 2008).

Today, Mimosa invisa is increasingly the subject of pharmacological studies. Thus, the toxic effect of fresh juice and antidiabetic activity of Mimosa invisa ethanol extract have been shown respectively by Usha (2009) and Harjanti (2009). The potential hypoglycemic effect of aqueous extract of this plant has been revealed by Mansroi (2011).

This study aims to evaluate the effect of the aqueous extract of leafy branches of Mimosa invisa (Fabaceae) on diuresis and urinary excretion of $\mathrm{Na}^{+}, \mathrm{K}^{+}$and $\mathrm{Cl}^{-}$in rats.

\section{Materials and Method}

\section{Plant Materiel}

The plant material consists of leafy branches of Mimosa invisa ex Mart. Colla (Fabaceae). This plant was harvested in Cocody and identified at the National Centre of Floristic of Felix Houphouet Boigny University (Abidjan, Ivory Coast). The identification was made by comparison with herbarium No. 7160 of 14 December 1963 Laurent Ake-Assi Emeritus Professor of Botany and No.199 of June 18, 1992 Emmanuelle Ake-Assi Doctor of Botany at 'Felix Houphouet Boigny Cocody University.

\section{Preparation of extract}

For extraction, $200 \mathrm{~g}$ of fresh leafy branches of Mimosa invisa (Fabaceae) are placed in 3 liters of distilled water and placed in boiling for 45 minutes. The decoction obtained is filtered first 3 times on absorbent cotton, and then 2 times on filter paper (Whatman No. 1). The filtrate collected was dried in an oven at $50{ }^{\circ} \mathrm{C}$ to obtain a yellow orange powder which is the aqueous extract of Mimosa invisa (Miv).

\section{Animal material}

Rats of the Rattus norvegicus species (Muridae), Wistar strain (Musa) coming from the animalery of the Training and Research Unit of Biosciences from the Felix HouphouetBoigny University, were used for this study. These animals weigh between 100 and $120 \mathrm{~g}$.

Study Method of diuretic activity and analysis of electrolytes

In a first series of experiment, 25 rats set out again in 5 batches of 5 in the cages metabolic and acclimatized during 48 hours. Before the tests, these animals are put at jeun during 18 hours before receiving each one 50 distilled water $\mathrm{ml} / \mathrm{kg}$ b.w. orally. Thereafter, the rats of the control batch receive $0,5 \mathrm{ml} \mathrm{NaCl} 9 \%$ by intraperitoneal way. The rats of the 4 other batches receive the aqueous extract of Mimosa invisa (Miv) to the respective doses of 5, 10, 15 and 20 $\mathrm{mg} / \mathrm{kg}$ b.w. and the urinary volume of the rats of each batch is measured during 24 hours.

In a second series of experiment 25 other rats set out again in 5 batches and put under the same conditions as those of the first series of experiment. The rats of the witness group also receive $0.5 \mathrm{ml}$ of $\mathrm{NaCl} 9 \%$ intraperitoneally. The rats of the 4 other batches receive $0,5 \mathrm{ml}$ of $20 \mathrm{mg} / \mathrm{kg}$ b.w. of the aqueous extract of Mimosa invisa (Miv), hydrochlorothiazide 


\section{International Journal of Science and Research (IJSR) \\ ISSN (Online): 2319-7064}

Index Copernicus Value (2013): 6.14 | Impact Factor (2015): 6.391

(Novartis Pharma, Switzerland), the spirolactone (Pfizer Holding France) and furosemide (Sanofi Aventis, France) respectively. The rats of each batch are treated with a dose of a substance. The method used for these tests is that of Gallez et al. (1999) as amended.

After the treatment of the rats with the various substances, the time of first micturition (TPM) is noted and urinary volume is measured during 24 hours.

Using a multi-parameter automated analyzer (Cobas C311 HITACHI, Roche), $\mathrm{Na}^{+}, \mathrm{K}^{+}$and $\mathrm{Cl}^{-}$are assayed in the urine of rats, freshly collected after 24 hours.

\section{Methods of statistical analysis and plot graphs}

Results are analyzed by analysis of variance ANOVA multiple comparison test of Tukey-Kramer. $\mathrm{P}<0.05$ is considered significant. The values are presented as average, followed by the error of the mean ( $\mathrm{M} \pm \mathrm{SEM})$. GraphPad Prism software (San Diego CA USA) is used to draw the graphs.

\section{Results}

3.1 Dose-response effect of an aqueous extract of Mimosa invisa (Fabaceae) on the volume of urinary excretion of rats

The intraperitoneal administration of Mimosa invisa aqueous extract (Miv), the doses of 5, 10, 15 and $20 \mathrm{mg} / \mathrm{kg}$ b.w., causes, with time, significant increases in the volume of urinary excretion some rats. These diuresis increases are dose-dependent (Figure 1). Miv is more active on diuresis at doses of $20 \mathrm{mg} / \mathrm{kg} \mathrm{b.w}$. and maximum effects of this extract are obtained about 08 hours after treatment.

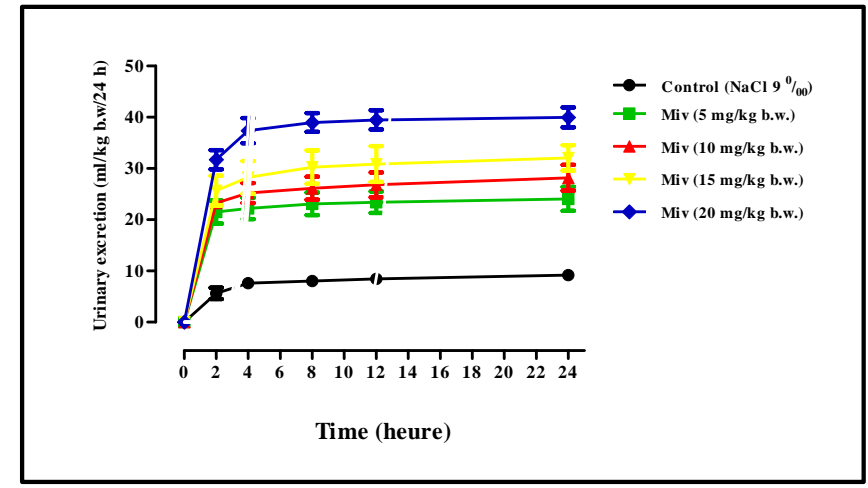

Figure 1: Dose response effect of aqueous extract of Mimosa invisa (Miv) on diuresis in rats $(\mathrm{n}=3)$

3.2 Effects of an aqueous extract of Mimosa invisa (Fabaceae), hydrochlorothiazide, furosemide and spirolactone on the volume of urinary excretion of rats

Treatment of rats with aqueous extract of Mimosa invisa (Miv), hydrochlorothiazide, or spirolactone furosemide brings up significant increases $(p<0.001)$ urine volume compared to control rats diuresis. Indeed, in the control rats, the urinary volume measured after 24 hours is of $10,46 \pm$ $0,98 \mathrm{ml} / \mathrm{kg}$ b.w. $/ 24 \mathrm{~h}$ (Table 1 ). When the rats are treated with Miv, hydrochlorothiazide, furosemide or spirolactone at doses of $20 \mathrm{mg} / \mathrm{kg}$ b.w, urinary volumes measured 24 hours after increase respectively of $293.5 \%, 312.5 \%, 264.7 \%$ and $330.7 \%$ compared to that of the rats in the control group. The volumes of urinary excretion, as measured 24 hours after the treatment of rats for 3 sets of experiments are given in Figure 2.

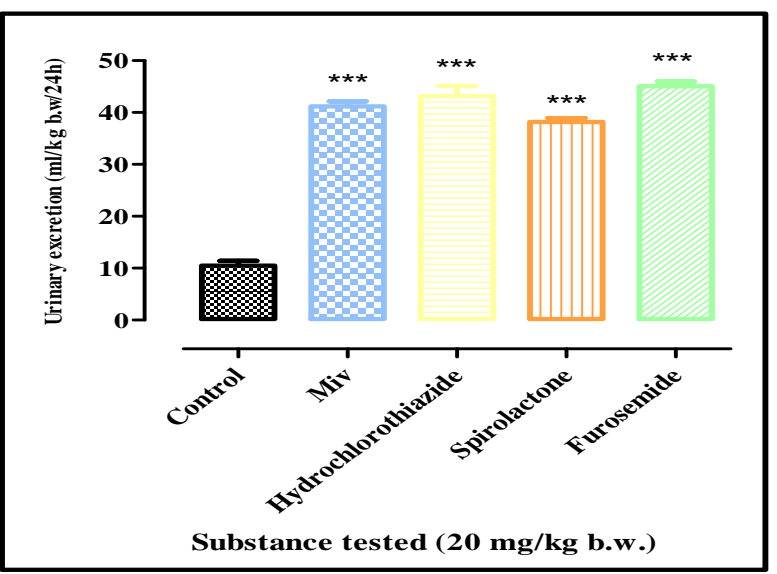

Figure 2: Effects of the aqueous extract of Mimosa invisa (Miv), hydrochlorothiazide, the spirolactone and furosemide on the volume of urinary excretion of rats $(n=3)$

$$
* * * \text { : }(\mathrm{P}<0.001)
$$

3.3 Effects of an aqueous extract of Mimosa invisa (Fabaceae), hydrochlorothiazide, furosemide and spirolactone on the time of first micturition (TFM) in rats

The intraperitoneal administration of aqueous extract of Mimosa invisa (Miv) at a dose of $20 \mathrm{mg} / \mathrm{kg}$ b.w leads to a reduction of the first time of micturition (TPM) to $40.06 \%$ (p $<0.001$ ) compared that of rats in the control group. Indeed, for 3 series of experiments, the TFM of the rats having received Miv is of 38,6 $\pm 1,8 \mathrm{~min}$, whereas that of the control rats is of $64,4 \pm 3,2 \mathrm{~min}$ (Table 1). Similarly, the administration of hydrochlorothiazide, spironolactone or furosemide cause significant reductions ( $p<0.001$ ) of TFM. Compared to the TFM of the control rats, the reductions are $47,51 \%, 19,25 \%$ and $53,72 \%$ respectively for the hydrochlorothiazide, the spirolactone and the furosemide with dose of $20 \mathrm{mg} / \mathrm{kg}$ b.w. (Figure 3).

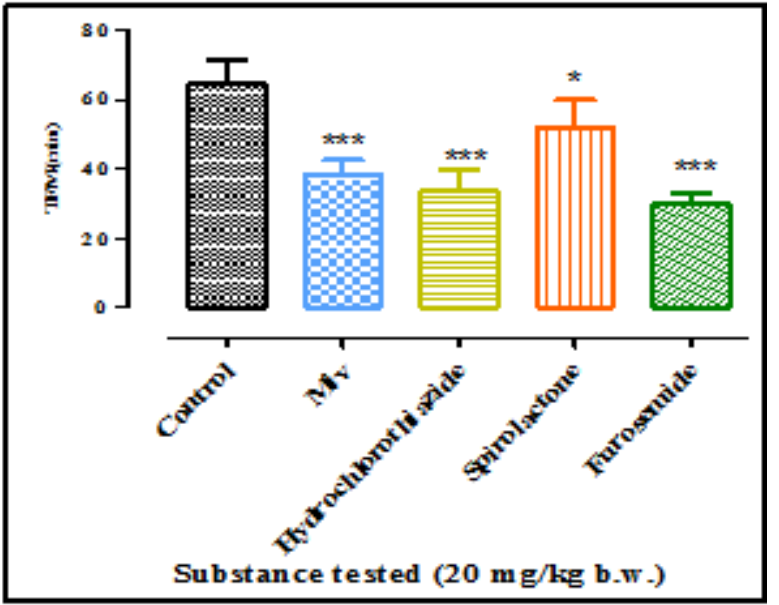

Figure 3: the first time micturition (TFM) in rats after administration of the aqueous extract of Mimosa invisa (Miv), hydrochlorothiazide, the spirolactone and furosemide $(\mathrm{n}=3)^{*}:(\mathrm{p}<0,05) ; * * *:(\mathrm{p}<0,001)$ 


\section{International Journal of Science and Research (IJSR) \\ ISSN (Online): 2319-7064 \\ Index Copernicus Value (2013): 6.14 | Impact Factor (2015): 6.391}

Table 1: The Urinary volumes and time of the first micturition (TFM) in rats after administration of the aqueous extract of Mimosa invisa (Miv), hydrochlorothiazide, the spirolactone and furosemide $(\mathrm{n}=3)$

\begin{tabular}{|c|c|c|}
\hline Substance tested & $\begin{array}{l}\text { Urinary Volume } \\
\text { (ml/kg b.w./24h) }\end{array}$ & $\begin{array}{c}\text { Time of first } \\
\text { micturition (min) }\end{array}$ \\
\hline Control ( $\mathrm{NaCl} 9 \%)$ & $10,46 \pm 0,98$ & $64,4 \pm 3,04$ \\
\hline Miv (20 mg/kg b.w.) & $41,16 \pm 1,87$ *** & $38,6 \pm 1,8 * * *$ \\
\hline $\begin{array}{c}\text { Hydrochlorothiazide } \\
(20 \mathrm{mg} / \mathrm{kg} \text { b.w. })\end{array}$ & $43,15 \pm 1,40 * * *$ & $33,8 \pm 2,76 * * *$ \\
\hline $\begin{array}{c}\text { Spirolactone } \\
(20 \mathrm{mg} / \mathrm{kg} \text { b.w. })\end{array}$ & $38,15 \pm 1,14 * * *$ & $52,00 \pm 3,63 *$ \\
\hline $\begin{array}{c}\text { Furosemide } \\
(20 \mathrm{mg} / \mathrm{kg} \text { b.w. })\end{array}$ & $45,05 \pm 0,80 * * *$ & $29,80 \pm 1,53 * * *$ \\
\hline
\end{tabular}

3.4 Effects of an aqueous extract of Mimosa invisa (Fabaceae), hydrochlorothiazide, the spirolactone and furosemide on the urinary excretion of sodium, potassium and chlorine in rats

The aqueous extract of Mimosa invisa (Miv), hydrochlorothiazide and furosemide significantly increase the levels of sodium, potassium and chlore. Indeed, Miv increases the rate of $\mathrm{Na}^{+}, \mathrm{K}^{+}$and $\mathrm{Cl}^{-}$respectively of $95.75 \%$, $107.7 \%$ and $29.93 \%$. For the hydrochlorothiazide, these increases are respectively 102,42 \%, 128,07 \% and 87,57 \% in the urines of the treated rats. With the furosemide, the rates of $\mathrm{Na}^{+}, \mathrm{K}^{+}$and $\mathrm{Cl}^{-}$increase by 169,69 \%, 237,7 \% and $70,06 \%$ respectively. By cons, the spirolactone reduces the potassium rate of $34,61 \%(\mathrm{p}<0,05)$, but does not have significant effects $(\mathrm{p}>0,05)$ on the chlorine and sodium rates in the urines of the treated rats. The effects of these substances on the urinary excretion of the ions sodium, potassium and chlorine in the rat are given by figures 4,5 and 6 . Table 2 indicates the rates after 24 hours of these ions in the urines of the control rats or treaties.

The urinary ratio $\mathrm{Na}^{+} / \mathrm{K}^{+}$of the rats treated with Miv, the hydrochlorothiazide and the furosemide does not vary significantly $(p>0,05)$ compared to that of the rats of the control batch. By cons, in the rats treated with the spirolactone, the ratio $\mathrm{Na}^{+} / \mathrm{K}^{+}$is of 2,05 $\pm 0,15(\mathrm{p}<0,01)$.

Table 2: Urinary chlorine and potassium, sodium rates in rats 24 hours after the administration of the aqueous extract of Mimosa invisa (Miv), of the hydrochlorothiazide, the spirolactone and the furosemide

\begin{tabular}{|c|c|c|c|}
\hline Substance tested & $\begin{array}{c}\mathbf{N a}^{+} \text {rate } \\
(\mathbf{m E q} / \mathbf{l} / \mathbf{2 4} \\
\boldsymbol{h})\end{array}$ & $\begin{array}{c}\boldsymbol{K}^{+} \text {rate } \\
(\mathbf{m E q} / \mathbf{I} / \mathbf{2 4} \\
\boldsymbol{h})\end{array}$ & $\begin{array}{c}\mathbf{C l}^{-} \text {rate } \\
(\mathbf{m E q} / \mathbf{I} / \mathbf{2 4} \\
\boldsymbol{h})\end{array}$ \\
\hline Control (NaCl 9 \%) & $33 \pm 4,56$ & $29,06 \pm$ & $62,8 \pm$ \\
& & 2,92 & 1,8 \\
\hline Miv (20 mg/kg b.w.) & $64,6 \pm$ & $60,38 \pm$ & $81,6 \pm$ \\
& $3,35^{* *}$ & $3,74^{* *}$ & $3,66^{* *}$ \\
\hline Hydrochlorothiazide (20 & $66,8 \pm$ & $66,26 \pm$ & $117,8 \pm$ \\
mg/kg b.w.) & $7,48^{* *}$ & $3,45^{* * *}$ & $1,68 * * *$ \\
\hline Spirolactone & $39 \pm$ & $19 \pm$ & $66,8 \pm$ \\
(20 mg/kg b.w.) & 1,81 & $2,59 *$ & 5,58 \\
\hline Furosemide & $89 \pm$ & $98,16 \pm$ & $106,8 \pm$ \\
(20 mg/kg b.w.) & $8,35^{* * *}$ & $8,79^{* * *}$ & $3,35^{* * *}$ \\
\hline
\end{tabular}

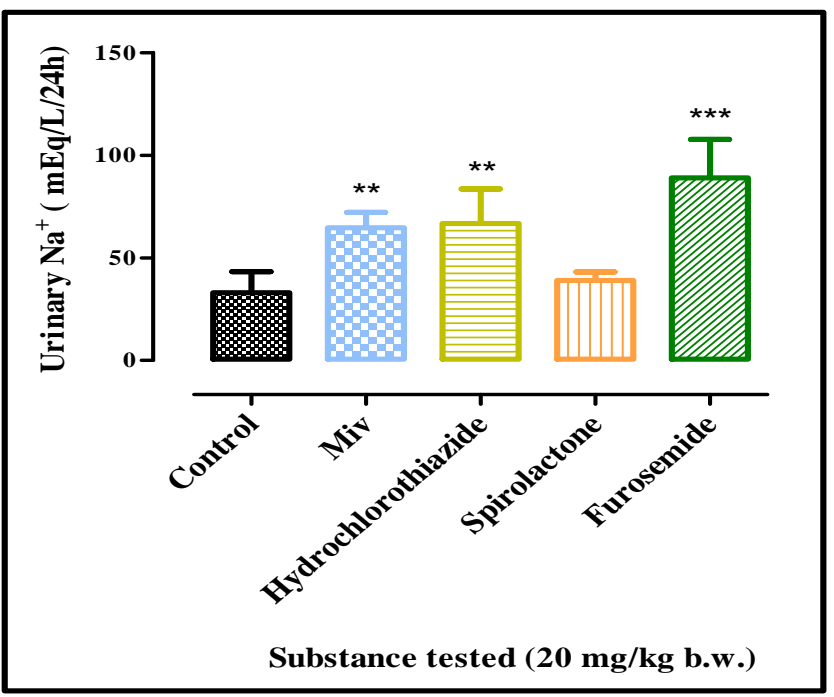

Figure 4:Urinary sodium rates in the rats 24 hours after the administration of the aqueous extract of Mimosa invisa (Miv) of the hydrochlorothiazide, the spirolactone and the furosemide $(\mathrm{n}=3)$

$* *:(\mathrm{p}<0,01) ; * * *:(\mathrm{p}<0,001)$

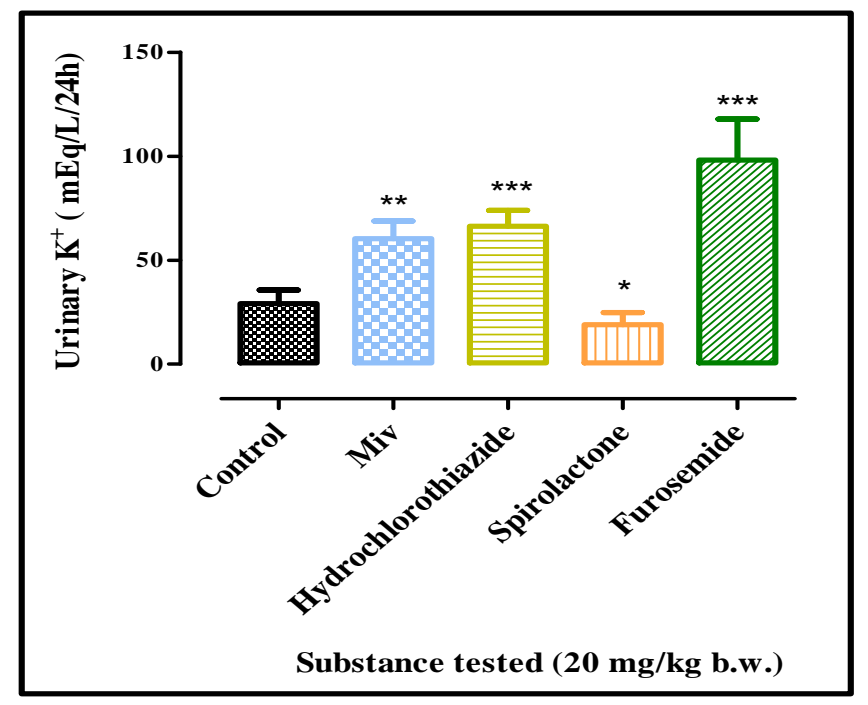

Figure 5:Urinary potassium rates in the rats 24 hours after the administration of the aqueous extract of Mimosa invisa (Miv) of the hydrochlorothiazide, the spirolactone and the furosemide $(\mathrm{n}=3)$

*: $(\mathrm{p}<0,05)$; **: $(\mathrm{p}<0,01) ; * * *:(\mathrm{p}<0,001)$

$* *:(\mathrm{p}<0,01) ; * * *:(\mathrm{p}<0,001)$ 


\section{International Journal of Science and Research (IJSR) \\ ISSN (Online): 2319-7064}

Index Copernicus Value (2013): 6.14 | Impact Factor (2015): 6.391

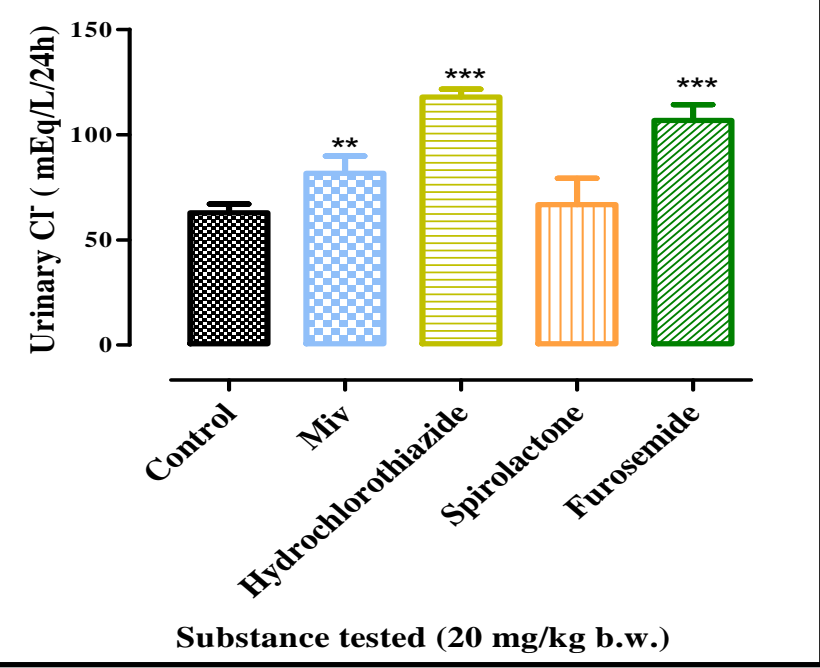

Figure 6:Urinary chlorine rates in the rats 24 hours after the administration of the aqueous extract of Mimosa invisa (Miv) of the hydrochlorothiazide, the spirolactone and the furosemide $(\mathrm{n}=3)$

$* *:(\mathrm{p}<0,01) ; * * *:(\mathrm{p}<0,001)$

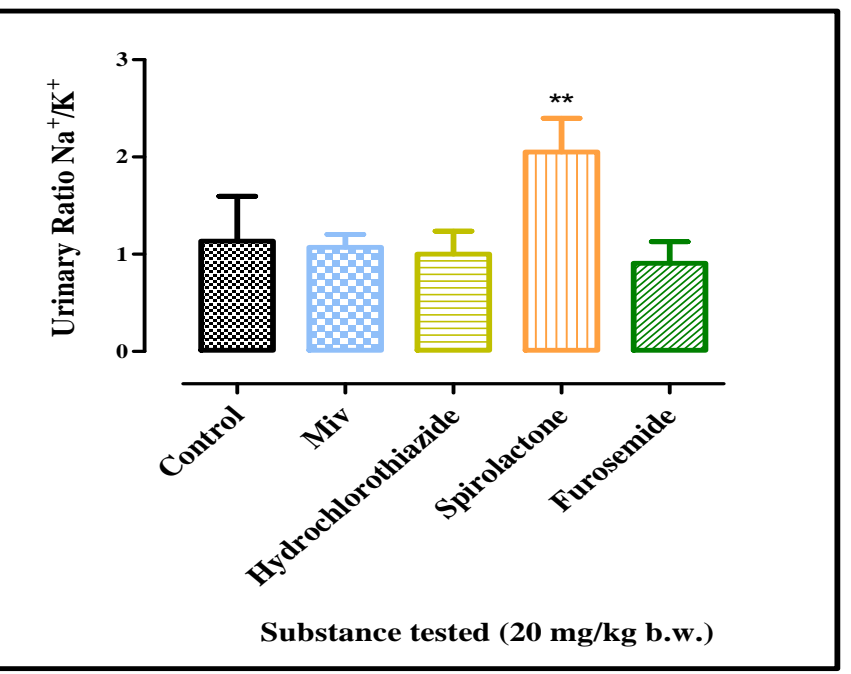

Figure 7: Ratio Sodium /potassium of the urinary excretion of the electrolytes in rats 24 hours after the administration of the aqueous extract of Mimosa invisa (Miv) of the hydrochlorothiazide, the spirolactone and the furosemide $* *:(p<0,01)$

\section{Discussion}

The aqueous extract of Mimosa invisa (Miv), at doses ranging from 5 to $20 \mathrm{mg} / \mathrm{kg}$ b.w, causes a dose-dependent and significant increase ( $\mathrm{p}<0.001$ ) of urinary excretion measured during 24 hours and at the dose $20 \mathrm{mg} / \mathrm{kg}$ b.w., a significant decrease $(p<0.001)$ of time of first micturition (TFM) in rats treated. The increase of the diuresis in the treated rats with Miv suggests that this extract is a diuretic. Indeed, diuretics are pharmacological agents aimed at increasing the volume of urine excreted (Safaridis, 2010). This increase of the volume of urine excreted induced by Miv could be due at a direct effect on the active components of transport, or an indirect purpose by modifying the pressures oncotic and hydrostatic in the peritubular capillaries (Lewy and Windhager, 1968; Brenner et al., 1969; Jouad and Al, 2001; Maghrani, 2005). This effect can be produced by the stimulation of regional blood circulation or the initial vasodilatation or by inhibiting the tubular reabsorption of water and the electrolytes (Pantoja et al.., 1993; Stanic and Samarzija, 1993). The reduction of the latency time is a characteristic of most plants diuretics (Sanogo, 2009). Thus, this reduction of the TFM induced by Miv confirms the diuretic properties of this extract.

In addition, the aqueous extract of Mimosa invisa causes a significant increase $(\mathrm{p}<0,01)$ in the urinary rate of excretion of $\mathrm{Na}^{+}, \mathrm{K}^{+}$and $\mathrm{Cl}^{-}$in the treated rats. This salidiuretic effect induced by Miv indicates that this extract inhibits the tubular reabsorption of these ions. This will result, by increased excretion of water. Under the same experimental conditions, the hydrochlorothiazide, the spirolactone and the furosemide at doses of $20 \mathrm{mg} / \mathrm{kg}$ b.w., also cause increasing in diuresis and reduces TPM in rats. The effects of Miv at $20 \mathrm{mg} / \mathrm{kg}$ b.w. are nearly identical to those of the hydrochlorothiazide, but less significant than those of the furosemide. However Miv are more active than the spirolactone on these measured parameters. Just like Miv, the hydrochlorothiazide and the furosemide provokes a significant increase in the urinary excretion rate of $\mathrm{Na}^{+}, \mathrm{K}^{+}$and $\mathrm{Cl}^{-}$.

For these three substances, the ratio $\mathrm{Na}^{+} / \mathrm{K}^{+}$does not vary significantly. By cons the spironolactone, a potassiumsparinger diuretic (aldosterone antagonist) has no significant effect on the rate of urinary excretion of $\mathrm{Na}^{+}$and $\mathrm{Cl}^{-}$, but reduces that of $\mathrm{K}^{+}(\mathrm{p}<0.05)$ and increases the ratio $\mathrm{Na}^{+} / \mathrm{K}^{+}$ significantly $(\mathrm{p}<0.01)$. It appears thus that Miv has diuretic and salidiuretic effects similar to those of the hydrochlorothiazide which is thiazidic diuretic, and furosemide which is diuretic of loop of Henlé. Thus Miv, just like hydrochlorothiazide and furosemide, could inhibit the reabsorption of $\mathrm{NaCI}$ in the distal convoluted tubule (dilution segment) and/or inhibit the level transport of loop of Henle, are thus opposed to the reabsorption of sodium and other ions (Bartoreli, 1959). The increase in the natriurèse would be accompanied by an increase of the renal excretion of water and proportionally of kaliurèse and chlorurie. The ratio $\mathrm{Na}^{+} / \mathrm{K}^{+}$characterizes serum aldosterone. Thus, if this ratio is lower than the normal, the secretion of the aldosterone decreases, whereas if it is higher than the normal the secretion of the aldosterone will be high (Nayak, 2013). Miv, unlike spirolactone, would not affect the serum aldosterone, which justifies its action more pronounced in the renal tubules. The increase by Miv of excretion of water and sodium also provides a basis for its hypotensive activity (Jouad, 2001).

\section{Conclusion}

This study shows that the effects of aqueous extract of Mimosa invisa (Fabaceae) on diuresis, TFM and urinary excretion of $\mathrm{Na}^{+}, \mathrm{K}^{+}$and $\mathrm{Cl}^{-}$are similar to those of certain diuretics, primarily hydrochlorothiazide, a thiazidic diuretic. The diuretic and salidiuretic effects of this extract may be beneficial in the treatment of some cases of hypertension in so far as it acts by urinary elimination of a part of the water 


\section{International Journal of Science and Research (IJSR) \\ ISSN (Online): 2319-7064}

Index Copernicus Value (2013): 6.14 | Impact Factor (2015): 6.391

and sodium present in the blood. This justifies the traditional use of this plant in the treatment of hypertension.

\section{References}

[1] C. Bartorelli, N. Gargano, A. Zanchetti (1959). Etude comparative de l'action salidiurétique del'hydrochlorothiazide et du chlorothiazide. J Suisse Med, 89(12): 331-334, (1959).

[2] B. M Brenner, K. H Falchuk, Keimowitz R. L., R. W. Berliner. The relationship between peritubular capillary protein concentration and fluid reabsorption by the renal proximal tubule. J Clin Invest, 48(8): 1519-1531, (1969).

[3] S. D. Dibong, Mpondo, M. E A. Ngoye, M. F Kwin, J. L. Betti. Ethnobotanique et phytomedecine des plantes médicinales de Douala, Cameroun. J Appl Biosci, 37 : 2496-2507, (2011).

[4] B. Gallez, R. Demeure, C. Baudelet, M. Geurts, A. Geubel, H. Roels. Evaluation par RMN de l'intoxication cérébrale par le manganèse. Louvain Med, 118: 165-168, (1999).

[5] C. A. Garcia. A survey of insects attacking giant sensitive plant (M. invisa) in Brazil with notes on its distributions. Brisbare, Australia: Queensland Department of Lands, 15 pp., (1982).

[6] Harjanti reslely, Sulastri. Effect of ethanolic leaf extract beret (Mimosa Invisa Mart) to decrease blood glucose levels in male rats oral glucose tolerance test. Ind. Sci. J. Database. 2:101-105, (2009).

[7] H. Jouad, M. Haloui, M. Rhiouani, J. El Hilaly, M. Eddouks. Ethnobotanical survey of medicinal plants used for the treatment of diabetes, cardiac and renal diseases in the North center region of Morocco (FezBoulemane). J Ethnopharmacol, 77: 175-182, (2001).

[8] H. Jouad, M. A. Lacaille-Dubois, M Eddouks. Chronic diuretic effect of the water extract of Spergularia purpurea in normal rat. J Ethnopharm, 75: 219-223, (2001).

[9] S. Larrue. Les plantes envahissantes en Polynésie Française : un exemple d'approche de la complexité en science de l'environnement. Vertigo-La Revue en Sciences de l'Environnement, 8(2) : 1-10, (2008).

[10] J. E. Lewy, E. E. Windhager. Peritubular control of proximal fluid reabsorption in the rat kidney. Amer $J$ Physiolo, 214(5): 943-954, (1968).

[11] Maghrani M., Zeggwagh N., Haloui M., Eddouks M. (2005).Acute diuretic effect of aqueous extract of Retama raetam in normal rats. $J$ Ethnopharmacol, 99:31-35.

[12] J. Mansroi, M. Z. Zaruwa, A. Mansroi. Potential hypoglycaemic effect of Nigerian anti-diabetic medicinal plants. J Complement Integr Med, 8(1): 1553-3840, (2011)

[13] B. S. Nayak, B. S. Dinda, P Elliah. Evaluation of diuretic activity of Gmelina arborea Roxb. Fruit extracts. Asian J Pharm Clin Res, 6(1): 111-113, (2013).

[14] C. V. Pantoja., L. C. H. Chiang., B. C. Norris., J. B. Concha. Diuretic, natriuretic and hypotensive effects produced by Allium sativum (garlic) in anaesthetized dogs. J Ethnopharmacol, 31: 325-331, (1993).
[15]R. Sanogo, A. H. Karidja., O. Dembele., D. Diallo. Activité diurétique et salidiurétique d'une recette utilisée en Médecine traditionnelle pour le traitement de l'hypertension artérielle. Mali Medical, 14(4): 1-6, (2009).

[16] G. Stanic, I. Samarzija. Diuretic Activity of Satureja Montana subsp. Montana extracts and oil in rats. Phytother Res, 7: 363-366, (1993).

[17]P. A. Sarafidis., P. I. Georgianos., A. N. Lasaridis. Diuretics in clinical practice. Part I: mechanisms of action, pharmacological effects and clinical indications of diuretic compounds. Expert Opinion on Drug Safety 9(2):243-57, (2010).

[18]P. T. A. Usha., N. Gopakumar., N. A. M. Chandrasekharan. Toxicity of fresh juice of Mimosa invisa in rabbits. $J$ Vet Anim Sci, 40: 6-8, (2009).

\section{Author Profile}

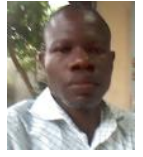

Irie Bi Jean Severin is titular of a Licence and Master of Animal Physiology and Pharmacology obtained respectively in 2009 and 2013 in the Training and Research Unit of Biosciences at Felix Houphouët Boigny University, Côte d'Ivoire. He is registered since 2013 in PhD at the Laboratory of Animal Physiology and Pharmacology where he works on the potentialities medicinal plants in the treatment of arterial hypertension. 